\title{
Crystalline Structure, Electrophysical and Magnetoresistive Properties of High Entropy Film Alloys
}

\author{
S.I. Vorobiov¹, D.M. Kondrakhova ${ }^{1}$, S.A. Nepijko, ${ }^{1,2}$ D.V. Poduremne ${ }^{1}$, N.I. Shumakova ${ }^{1}$, I.Yu. Protsenko ${ }^{1}$ \\ 1 Sumy State University, 2, Rymskogo-Korsakova st., 40007 Sumy, Ukraine \\ 2 University of Mainz, 7, Staudingerweg, 55128 Mainz, Germany
}

(Received 15 April 2016; published online 03 October 2016)

\begin{abstract}
The results of research the phase composition and electrophysical (resistivity, thermal coefficient of resistance, strain coefficient) and magnetoresistive properties (anisotropic magnetoresistance) of thin films (to $40 \mathrm{~nm}$ ) high entropy alloys (HEA) based on $\mathrm{Al}, \mathrm{Cu}, \mathrm{Ni}, \mathrm{Cr}, \mathrm{Fe}$, Co and Ti. It is established that after forming the layered samples by electron condensation on diffraction pattern fixed lines from the two phases of the fcc lattice and actually tracks the bcc phase. After homogenization by annealing the samples is one of the fcc phase s.s. HEA and traces bcc phase (likely s.s. $(\alpha-\mathrm{Fe}, \mathrm{Cr})$ ), that samples are single phase. The study electrical properties allowed watching the first double-stage plastic deformation of a large value of the coefficient gauge (300 units), watch probably, is typical for HEA. The character dependences MR from induction indicates to realization of anisotropic magnetoresistance.
\end{abstract}

Keywords: High entropy alloys, Thin films, Thermal coefficient of resistance, Strain coefficient, Anisotropy magnetoresistance.

DOI: $10.21272 /$ jnep.8(3).03026

PACS numbers: $61.66 . \mathrm{Xx}, 62.20 . \mathrm{F}-$, 75.47.Np

\section{INTRODUCTION}

In the last decade is conducted intensive research of crystal structure and mechanical properties of the new class of materials - high entropy alloys (HEA), whose improve properties were first noticed by the authors [1]. Since these alloys are formed from 5-13 elements (mainly HCC and refractory bcc or hcc metals), they have high entropy of mixing $\left(\Delta S_{m i x}\right)$, then the HEA have more stable phase in a bcc or fcc solid solution (s.s.) compared to intermetallic compounds and other complex structures (see., eg, [2]).

Depending on the concentration of some component (eg atoms $\mathrm{Ni}$ ) can simultaneously stabilize the fcc and bcc s.s. [2-5] or bcc s.s. - $(\alpha-\mathrm{Fe}, \mathrm{Cr})$ and intermetallic AlNi [6] in a bulk HEA AlCrFeCoNiCu. Nitride phase of HEA based on Ti, V, Cr, Zr and Hf have fcc lattice [7-9].

Although the metallic phase have bcc lattice [7] analysis [2], we conclude that stabilizing the fcc or bcc completely determined by average concentration of valence electrons per atom located in the valence band of the alloy, at a concentration of less 7.2 el./at. formed bcc phase at 7.2-8.2 el./at. - two-phase composition fcc + bcc stabilized and at concentrations greater 8.2 el./at. - fcc phase s.s. HEA.

In nitride phase HEA based on $\mathrm{Al}, \mathrm{Cr}, \mathrm{Nb}, \mathrm{Ti} \mathrm{Si}$ semiconductor and also stabilizes the fcc phase (see., for example, $[11,12])$. Analysis of the results [1-12] indicates that the feature of conducted studies is that the HEA bulk samples obtained by vacuum- arc [7] or magnetron [8-12] sputtering. The peculiarity of our experiments consists firstly in the fact that formation of s. s. made by layer by layer condensation of some individual components of thickness $8 \mathrm{~nm}$ (total thickness $-40 \mathrm{~nm}$ ), which, thanks to condensation-stimulated diffusion and low thickness, causing mixing of atoms and forming s.s.

Secondly, the aim of our work was to study not only of HEA phase, but also electrophysical and magnetoresistive properties in what consists a large degree of novelty of the obtained results.

\section{METHODOLOGY AND TECHNIQUES EXPERIMENT}

The film samples are condensed with metod layer by layer condensation wiyh control the thickness of the individual layers by quartz crystal method. For the diffraction and electron-microscopic studies was used NaCl-substrate (S), and for the resistance and magnetoresistance measured - lining with ceramics.

Strain coefficient measured by the method [13-14] using polystyrene substrates. The concentration of component was calculated and refined by EDX analysis. The calculation of entropy of mixing $\left(\Delta S_{m i x}\right)$, as a criterion HEA performed on ratio [15] (see. also [2]):

$$
\Delta S_{m i x}=-R \sum_{i=1}^{n} c_{i} \ln c_{i}
$$

where $i$ and $c_{i}$ - the number and atomic (molar) concentrations of $i$-components.

In the Table 1 shows general characteristics of the samples. Mark that the samples with seven components No $1^{\prime}$ and No 2' are different from the six-component samples No 1 and No 2 only additional layer of Ti. Also note that the elemental composition of samples No 1 and No 2 responsible of samples studied by the authors of [2, 6]. Note also that the value $\Delta S_{\text {mix }}$ samples No 1 and No 2 is consistent with $\Delta S_{\text {mix }}=14,30$ and $14.90 \mathrm{~J} /(\mathrm{mol} \cdot \mathrm{K})$ [2].

Based on the temperature dependence of the resistivity $(\rho)$ (II temperature cycle at the cooling) calculated thermal coefficient of resistance (TCR) base on ratio $\beta=\frac{\rho(T)-\rho(300)}{\rho(300)(T-300)}$. Integral value of strain coefficient determined based on depending $\Delta R / R(0)$ versus on the value of longitudinal strain $\varepsilon l$ based on the ratio $\gamma_{l}=\frac{R\left(\varepsilon_{l}\right)-R(0)}{R(0) \varepsilon_{l}}$. The value of magnetoresistance (MR) calculated on the basis of field 
Table 1 - General characteristics of HEA films

\begin{tabular}{|l|l|l|l|}
\hline No & Sample (thickness, $\mathrm{nm})$ & $c_{i}$, at. $\%$ & $\Delta$ Smix, J/(mol·K) \\
\hline 1 & $\mathrm{Cr}(7,5) / \mathrm{Al}(4,5) / \mathrm{Co}(7,3) / \mathrm{Cu}(4,8) / \mathrm{Ni}(7) / \mathrm{Fe}(7) / \mathrm{S}$ & $19 / 8 / 21 / 12 / 19 / 19 / \mathrm{S}$ & 14,58 \\
\hline $1^{\prime}$ & $\mathrm{Ti}(2,2) / \mathrm{Cr}(7,5) / \mathrm{Al}(4,5) / \mathrm{Co}(7,3) / \mathrm{Cu}(4,8) / \mathrm{Ni}(7) / \mathrm{Fe}(7) / \mathrm{S}$ & $4 / 18 / 9 / 20 / 12 / 19 / 18 / \mathrm{S}$ & 15,33 \\
\hline 2 & $\mathrm{Al}(4) / \mathrm{Cu}(3,2) / \mathrm{Co}(4,5) / \mathrm{Cr}(5,2) / \mathrm{Fe}(4,7) / \mathrm{Ni}(4) / \mathrm{S}$ & $11 / 13 / 19 / 20 / 19 / 17 / \mathrm{S}$ & 14,76 \\
\hline $2^{\prime}$ & $\mathrm{Ti}(2,5) / \mathrm{Al}(4) / \mathrm{Cu}(3,2) / \mathrm{Co}(4,5) / \mathrm{Cr}(5,2) / \mathrm{Fe}(4,7) / \mathrm{Ni}(4) / \mathrm{S}$ & $6 / 11 / 12 / 18 / 18 / 19 / 16 / \mathrm{S}$ & 17,72 \\
\hline
\end{tabular}

dependence $R(B)$ based on ratio $M R=\frac{R\left(B_{i}\right)-R(0)}{R(0)}$. To measure $\rho(T), R\left(\varepsilon_{l}\right)$ and $R\left(B_{i}\right)$ and calculate $\beta, \gamma_{l}$ and MR used appropriate computerized complex.

\section{RESULTS AND DISCUSSION}

\subsection{Crystalline Structure}

Electron microscopic study (Fig. 1) indicate that in the initial state (after condensation) crystal structure are exclusively disperse (average crystallite size $L \leq 10 \mathrm{~nm}$ ), although with annealing the samples to $850 \mathrm{~K}$ beside with this structure is formed of fine fraction with size $L \cong 50 \mathrm{~nm}$. The character of electron diffraction (Fig. 1, insert) indicates that at the stage of condensation in HEA film formed two fcc and bcc phase (so called B2 phase [2]). A similar phase composition the authors [2] observed. Formation hcc1 and hcc2 phases associated with the not finished process of forming s.s. HEA, although with annealing the samples to $850 \mathrm{~K}$ happening homogenization alloy and formation s.s. HEA with hec lattice based on the fcc1 and fcc2 (Fig. 1d). Most likely one of the fcc phase initially formed as s.s. HEA, the other was a metastable phase based on $\mathrm{Al}$ and $\mathrm{Ni}$ [6], which collapsed during annealing. According to the findings [6] bcc phase can be magnetic s.s. $(\alpha-\mathrm{Fe}, \mathrm{Cr})$. In this case it will be possible to realize the magnetic domains based on two s.s., that will cause highs accommodation on Fig. 4 a, b (800 K) and Fig. 4 c (300 and 800 K).

Gray background between diffraction lines (111) and (200) indicates to its specific disorder and vacancy defects. The annealing of samples promotes healing of defects and ordering of some s.s. (Fig. $1 \mathrm{~d}$ ). It should be noted that the reflexes from oxides $\mathrm{Al}_{2} \mathrm{O}_{3}$ and $\mathrm{Cr}_{2} \mathrm{O}_{3}$ have a point character and small intensity, which is associated with a small effective thickness of layers of $\mathrm{Cr}$ and $\mathrm{Al}$. Also note that from bcc phase (phase B2) was observed in [2], fixed two very weak line (200) and (220), while the most intense line (110) not fixed.

Mark that the average value of the parameter fcc lattice s.s. very good agreement with the corresponding parameter for s.s. (Cu, Ni) $a=0,352-0,366 \mathrm{~nm}$ [17]. Also, we note that the addition of a thin layer of $\mathrm{Ti}$ (1' and $2^{\prime}$ samples) does not affect their phase composition.

The fact that in this case, annealed HEA actually have only hcc - phase requires additional explanation. It is known (see., for example, $[15,16]$ ) that the formation of HEA is the performance of conditions: the value of $\Delta S_{\text {mix }}$ six-components alloy should be more $\Delta S_{\text {mix }}=1,75 R=14,54 \mathrm{~J} /(\mathrm{mol} \cdot \mathrm{K})$ for equiatomic alloy and parameters of difference atomic size

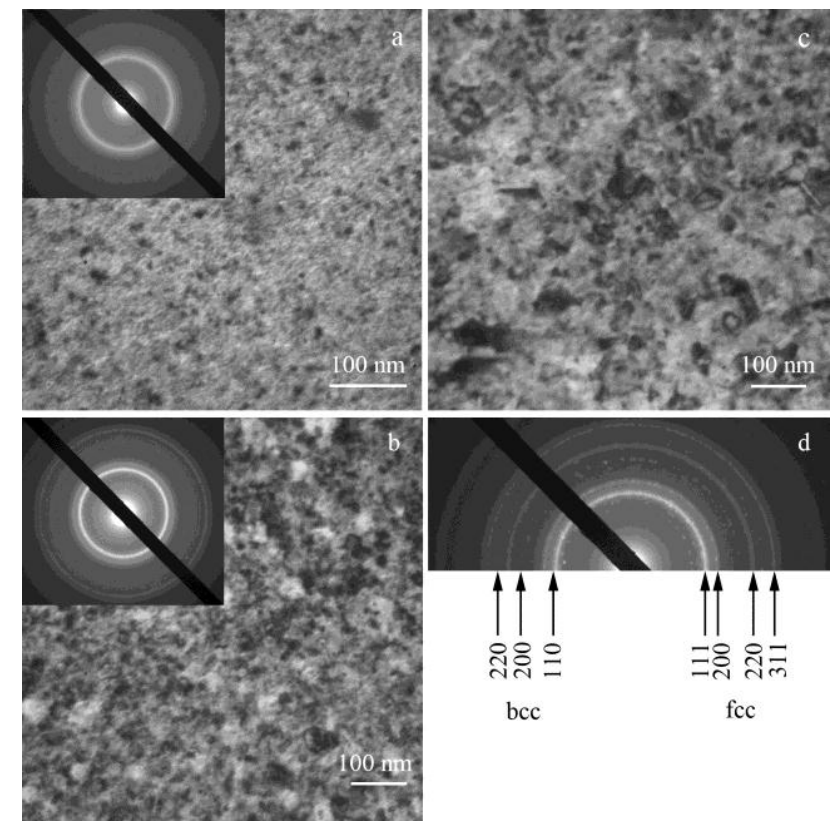

Fig. 1 - Microstructure and diffraction patterns from sample No 1 (a, b) and No 2 (c, d), the annealing temperature, $\mathrm{K}$ : 300 (a), 600 (b) and 850 (c, d)

Table 2 - Decipherment of diffraction pattern shown in Fig. 1d

\begin{tabular}{|c|c|c|c|c|}
\hline No & $d_{h k l}, \mathrm{~nm}$ & $h k l$ & $a, \mathrm{~nm}$ & Phase \\
\hline 1 & 0,2610 & - & - & $\mathrm{Cr}_{2} \mathrm{O}_{3}$ \\
\hline 2 & 0,2373 & - & - & $\mathrm{Al}_{2} \mathrm{O}_{3}$ \\
\hline 3 & 0,2373 & - & - & $\mathrm{Cr}_{2} \mathrm{O}_{3}$ \\
\hline 4 & 0,2175 & 111 & 0,3616 & s.s. \\
\hline 5 & 0,2088 & 200 & 0,3600 & s.s. \\
\hline 6 & 0,1420 & 200 & 0,2840 & bcc \\
\hline 7 & 0,1272 & 220 & 0,3597 & s.s. \\
\hline 8 & 0,1010 & 220 & 0,2850 & bcc \\
\hline 9 & 0,10870 & 311 & 0,3605 & s.s. \\
\hline \multicolumn{7}{|c|}{$a$ (s.s.) $=0,3604 \mathrm{~nm}$} \\
\hline
\end{tabular}

$$
\delta=\sqrt{\sum_{i=1}^{n} c_{i}\left(1-\frac{r_{i}}{\vec{r}}\right)^{2}}
$$

where $r_{i}$ - atomic radius i-component; $\vec{r}=\sqrt{\sum_{i=1}^{n} c_{i}} r_{i}-$ average atomic radius, should be less $6.6 \%$ (in our case $\delta<1 \%$ ). Implementation of these two conditions causes formation HEA.

\subsection{Electrophysical Properties}

On Fig. 2 shows a typical dependence of the resistivity and TCR (inset) for HEA. Characteristic features of samples is relatively high TCR $\left(\sim 10^{-3} \mathrm{~K}^{-1}\right)$ and the concentration of defects in the crystal structure 

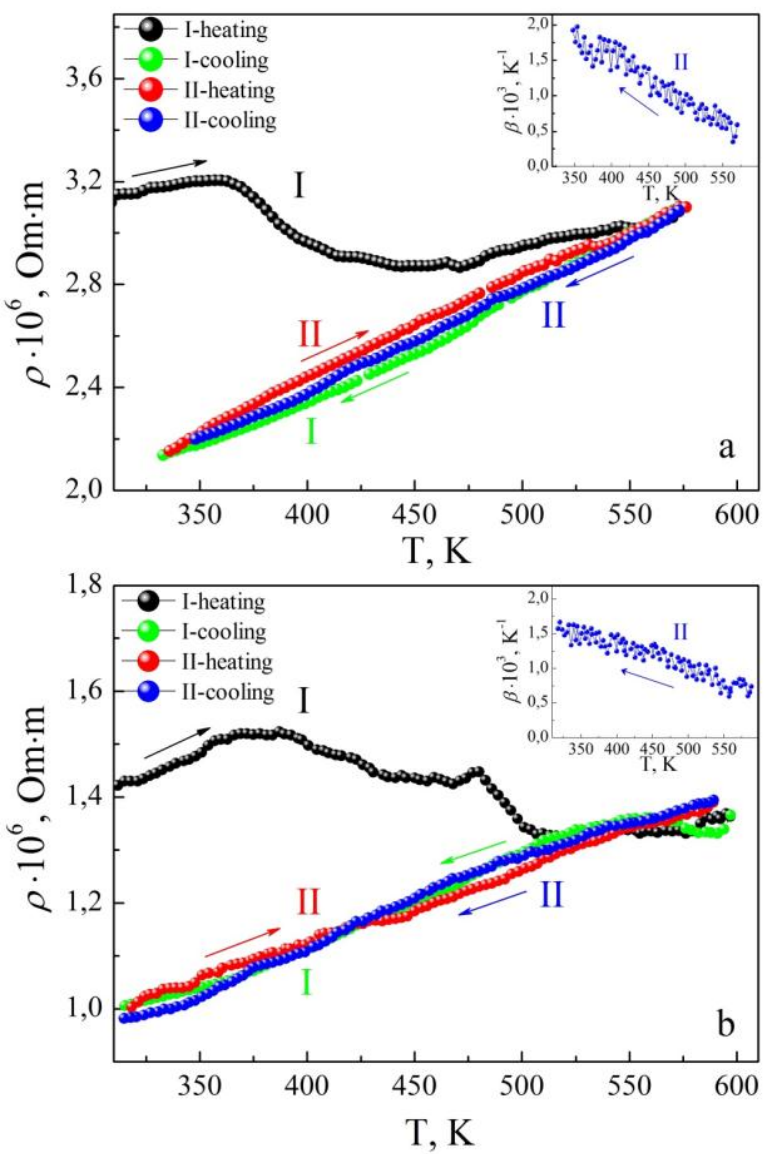

Fig. 2 - The dependence of the resistivity and TCR (inset) versus temperature annealing for sample No 2 (a) and No 2 ' (b); I, II - the number of temperature cycles

of the "vacancy - interstitial atoms", which reduce the resistivity at the annealing in the first cycle of «heating - cooling".

At the study of strain coefficient (SC) of HEA, we, probably, first observed strain effect feature, which is illustrated in Fig. 3. At the strain in the range $\Delta \varepsilon_{l}=(0-1) \%$ happening of the transition from elastic to plastic strain (we call it plastic strain type I) is at (Fig. 3a).

At the I strain cycle on the range $\Delta \varepsilon_{11} \cong(0-0,5) \%$ the value strain coefficient $\gamma_{l} \cong 12,0$, and range $\Delta \varepsilon_{l^{2}} \cong(0,5-1,0) \%, \gamma_{l} \cong 300$ and $\gamma_{l I I, I I I} \cong 25$ that can take place only in semiconductor films. In these II and III cycles of strain observed linear dependence of $\Delta R / R(0)$ versus $\varepsilon_{l}$, value of SC $\gamma_{l} \cong 12,5$.

At this stage, sold, most likely after the relaxation effect quasiplastic strain of I type. With further strain to $\varepsilon_{l}=2 \%$ is the transition to plastic strain of II type at $\varepsilon_{l t r}^{\prime \prime} \cong 1 \%$ (Fig. $3 \mathrm{~b}$ ). This transition is accompanied by an increase of value SC up $\gamma_{l I I, I I I} \cong 12,5$ to $\gamma_{l} I V$, which is a significant value. At the $\mathrm{V}$ and VI strain cycles there is also a kind of strain to quasiplastic because there was a relaxation of plastic strain of the II type.
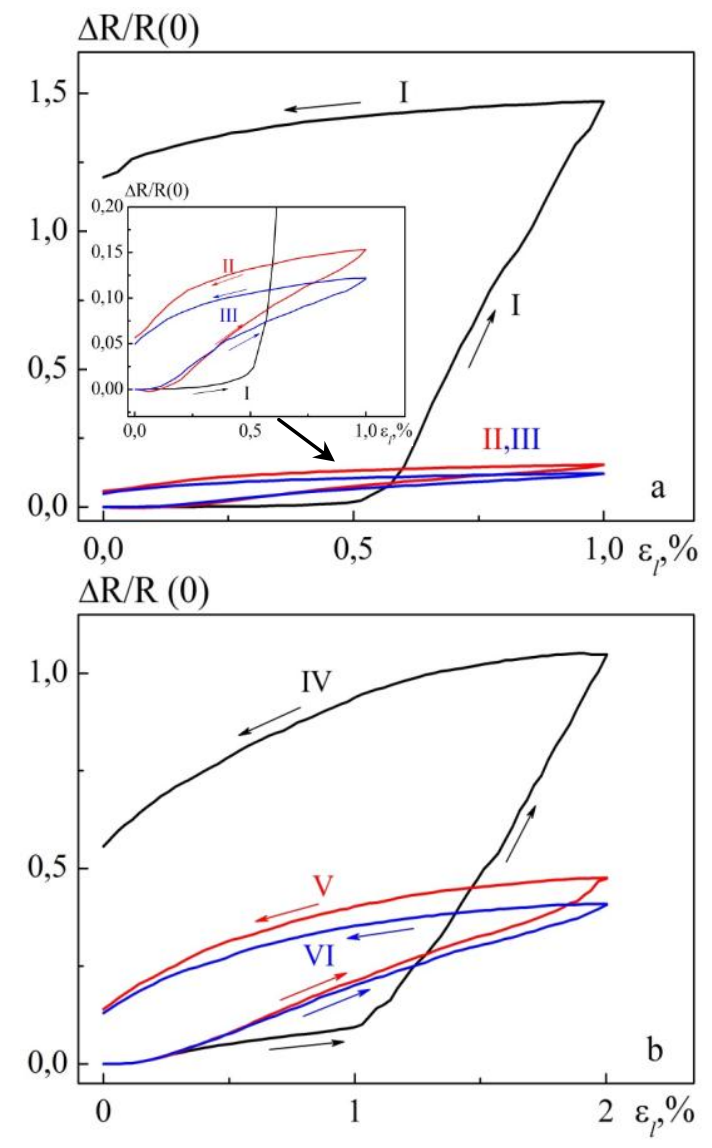

Fig. 3-Strain dependences for sample No 2, which illustrated of two-stage plastic strain

Described feature of two-stage at the strain effect never observed in the case of single-layer or multilayer films (see., for example, review [18, 19]), with their plastic strain.

\subsection{Magnetoresistive Properties}

Research of MR were performed in geometry CIP (current $j$ in the film plane) at the three relative orientation of the magnetic field: longitudinal $(||)$, transverse $(+)$ and perpendicular $(\perp)$ at an operating current from 0.5 to $1 \mathrm{~mA}$. Typical MR magnetoresistive depending on the induction B shown in Fig. 4. Since bcc, s.s. HEA typical ferromagnetic [6], without elements of granular state, then it is a anisotropic magnetoresistance (AMR), which is clearly manifested in position and, on the one hand, and the positions $b$ and c, on the other hand (Fig. 4).

The effect of annealing to $800 \mathrm{~K}$ leads to some increase in the amplitude of the MR (positions a and b), while in the case with the amplitude of the MR virtually unchanged. The relatively small size of the amplitude explained small thickness $(40 \mathrm{~nm})$ and very small value of the working current. Splitting the maximum on the dependence of MR due with to domain structure fec s.s. HEA.

\section{CONCLUSION}

The crystal structure, electrophysical (resistivity, TCR and SC) and magnetoresistive properties (AMR) of 

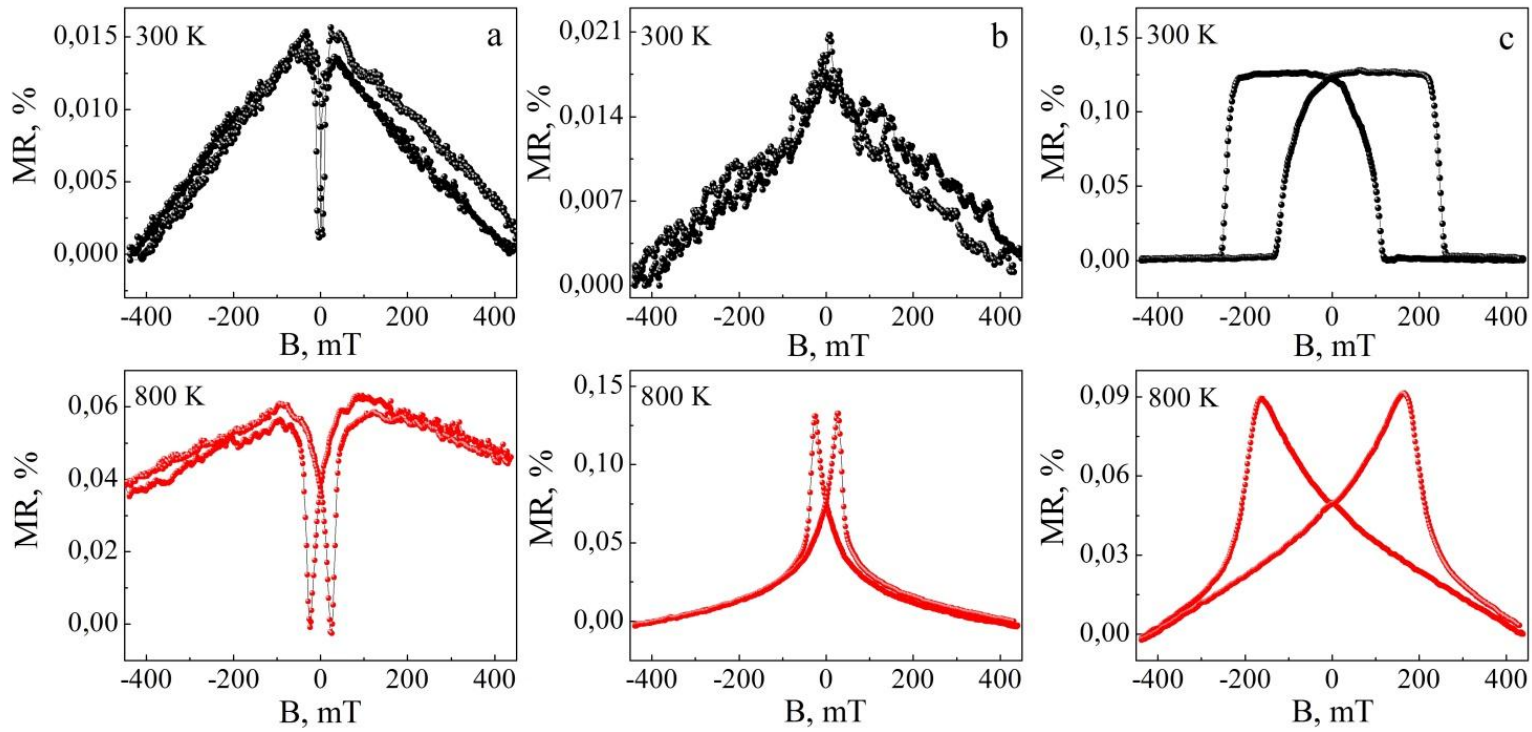

Fig. 4 - Dependence MR from induction $B$ for the sample No 2 at the three orientations of induction relative to the electric current: longitudinal (a), transverse (b) and perpendicular (c)

film $\mathrm{HEA}$ based on $\mathrm{Cr}, \mathrm{Fe}, \mathrm{Al}, \mathrm{Cu}, \mathrm{Ni}$ and $\mathrm{Co}$ were studies. Established immediately after condensation of the film it is formed, probably three phases: fcc1 (s.s. HEA), fcc2 (possibly metastable AlNi) and bcc (possibly s.s. $(\alpha-\mathrm{Fe}, \mathrm{Cr}))$. During annealing fcc phase 2 breaks and s.s. $(\alpha-\mathrm{Fe}, \mathrm{Cr})$ actually disappears, because the electron from it recorded only 2-3 very faint line.

\section{ACKNOWLEDGEMENT}

One of the authors (S.A. Nepijko) expresses gratitude Prof. Ertl G. (Fritz Haber Institute of the Max Planck Society, Berlin) for the interest and discussion of its results.

The work performed under the state budget subject No 0115U000689 (2015-2017 years) by funding the Ministry of Education and Science of Ukraine.

\title{
Кристалічна структура, електрофізичні та магніторезистивні властивості плівкових високоентропійних сплавів
}

\author{
С.I. Воробйов ${ }^{1}$, Д.М. Кондрахова ${ }^{1}$, С.О.Непийко ${ }^{1,2}$, Д.В. Подуремне ${ }^{1}$, Н.І. Шумакова ${ }^{1}$, \\ I.Ю. Проценко ${ }^{1}$ \\ ${ }^{1}$ Сулський державний університет, вул. Римського-Корсакова, 2, 40007 Сули, Україна \\ 2 University of Mainz, 7, Staudingerweg, 55128 Mainz, Germany
}

\begin{abstract}
Представлені результати дослідження фазового складу, електрофізичних та магніторезистивних властивостей тонких плівок (до 40 нм) високоентропійних сплавів на основі $\mathrm{Al}, \mathrm{Cu}, \mathrm{Ni}, \mathrm{Cr}, \mathrm{Fe}, \mathrm{Co}$ та Ti. Установлено, що після формування зразків шляхом пошарової конденсації на електронограмах фіксуеться лінії від двох фаз із ГЦК решіткою і фактично сліди ОЦК фази. Після гомогенізації шляхом термовідпалювання зразків залишаеться одна ГЦК фаза т.р. ВЕС і сліди ОЦК фази (скоріше за все т.p. $(\alpha-\mathrm{Fe}, \mathrm{Cr}))$, тобто зразки е однофазними. Дослідження електрофізичних властивостей дозволило вперше спостерігати двостадійну пластичну деформацію із великим значенням коефіціента тензочутливості (до 300 одиниць) е характерним для ВЕС. Характер залежностей МО від індукції вказуе на реалізацію анізотропного магнітоопору.
\end{abstract}

Ключові слова: Високоентропійні сплави, Тонкі плівки, Термічний коефіціент опору, Тензочутливість, Анізотропний магнітоопір. 


\title{
Кристаллическая структура, электрофизические и магниторезистивные свойства пленочных высокоэнтропийных сплавов
}

\author{
С.И. Воробьев ${ }^{1}$, Д.М. Кондрахова ${ }^{1}$, С.А.Непийко ${ }^{1,2}$, Д.В. Подуремне ${ }^{1}$, Н.И. Шумакова ${ }^{1}$, \\ И.Е. Проценко ${ }^{1}$ \\ ${ }_{1}$ Сулский государственный университет, ул. Рилского-Корсакова, 2, 40007 Суль,, Украина \\ 2 University of Mainz, 7, Staudingerweg, 55128 Mainz, Germany
}

\begin{abstract}
Представлены результаты исследования фазового состава, электрофизических и магниторезистивных свойств тонких пленок (до 40 нм) высокоэнтропийных сплавов на основе $\mathrm{Al}, \mathrm{Cu}, \mathrm{Ni}, \mathrm{Cr}, \mathrm{Fe}$, Cо и $\mathrm{Ti}$. Установлено, что после формирования образцов путем послойной конденсации на электронограммах фиксируется линии от двух фраз с ГЦК решеткой и фактически следы ОЦК фразы. После гомогенизации путем термоотжига образцов остается одна ГЦК фаза т.р. ВЭС и следы ОЦК фазы (скорее всего т.р. $(\alpha-\mathrm{Fe}$, Cr)), то есть образцы являются однофазными. Исследование электрофизических свойств позволило впервые наблюдать двостадийную пластическую деформацию с большим значением коэффициента тензочувствительности (до 300 единиц) характерной для ВЭС. Характер зависимостей МС от индукции указывает на реализацию анизотропного магнитосопротивления.
\end{abstract}

Ключевые слова: Высокоэнтропийные сплавы, Тонкие пленки, Термический коэфроициент сопротивления, Тензочувствительность, Анизотропное магнитосопротивление.

\section{REFERENCES}

1. J.W. Yeh, S.K. Chen, S.J. Lin, J.Y. Gan, T.S. Chin, T.T. Shun, C.H. Tsau, S.Y. Chang, Adv. End. Mater. 6, 299 (2004).

2. M.V. Karpets, O.S. Makarenko, O.M. Myslyvchenko, V.F. Horban, Naukovi visti NTUU «KPI» 2, 46 (2014).

3. M.V. Karpets, O.S. Makarenko, O.M. Myslyvchenko, M.O. Krapivka, V.F. Horban, A.V. Samelyuk, Problem. Friction Wear 63, 103 (2014).

4. B.S. Li, Y.P. Wang, M.X. Ren, C. Yang, H.Z. Fu, Mat. Sci. Eng. A 498, 482 (2008).

5. M.F. del Grosso, G. Bozzolo, H.O. Mosca, Physica B 407, 3285 (2012).

6. Y.P. Wang, B.S. Li, H.Z. Fu, Adv. Eng. Mater. 11 No 8, 641 (2009).

7. A.D. Pogrebnjak, V.N. Borisyuk, A.A. Bagdasaryan, O.V. Maksakova, E.V. Smirnova, J. Nano- Electron. Phys. 6 No 4, 04018 (2014).

8. A.D. Pogrebnjak, I.V. Yakushchenko, A.A. Bagdasaryan, O.V. Bondar, R. Krause-Rehberg, G. Abadias, P. Chartier, K. Oyoshi, Y. Takeda, V.M. Beresnev, O.V. Sobol, Mater. Chem. Phys. 147, 1079 (2014).

9. D.C. Tsai, Z.C. Chang, L.Y. Kuo, T.J. Lin, T.N. Lin, M.H. Shio, F.S. Shieu, Thin Solid Films 544, 580 (2013).
10. K.-H. Cheng, C.-H. Weng, C.-H. Lai, S.-J. Lin, Thin Solid Films 517, 4989 (2009).

11. P.K. Huang, J.W. Yeh, Scripta Materialia 62, 105 (2010).

12. M.H. Hsieh, M.H. Tsai, W.J. Shen, J.W. Yeh, Surf. Coat. Technol. 221, 118 (2013).

13. K.V. Tyschenko, I.Yu. Protsenko, Metalofiz. Nov. Teknol. 34, No 7, 907 (2012)

14. I.M. Pazukha, Z.M. Makukha, Yu.M. Shabelnyk, I.Yu. Protsenko, J. Nano-Electron. Phys. 4 No 3, 03020 (2012)

15. Y. Zhanga, Y. Zhou, Mater. Sci. Forum 561, 1337 (2007).

16. A. Manzoni, H. Daond, R. Völxl, U. Glatzel, N. Wanderka, Ultramicroscopy 132, 212 (2013).

17. S.M. Kalinichenko, O.P. Tkach, T.M. Hrychanovska, L.V. Odnodvorets, J. Nano- Electron. Phys. 7 No 4, 04048 (2015).

18. I. Protsenko, L. Odnodvoretz, A. Chornous, Metallofiz. Nov. Tekhnol. 20, 36 (1998).

19. S.I. Protsenko, L.V. Odnodvorets, I.Yu. Protsenko, Chapter in Springer Proceedings in Physics "Nanocomposites, Nanophotonics, Nanobiotechnology and Application”156, 345 (2014). 